Brit. J. vener. Dis. (1962), 38, 209.

\title{
ARGUMENTS IN FAVOUR OF A VIRUS AETIOLOGY OF
}

\author{
NON-GONOCOCCAL URETHRITIS ILLUSTRATED BY
}

\section{THREE CASES OF REITER'S DISEASE*}

BY

\author{
A. SIBOULET AND P. GALISTIN \\ Hôpital Saint-Louis, Paris
}

The presence of French troops in Algeria since 1956 has provided an opportunity for studying the frequency of Reiter's disease in France and French overseas territories. Each year several hundred cases were diagnosed. Military medical statistics confirm this, and Pernod and Mesmin (1961) have reported a study of the condition based on 121 cases.

We have studied this syndrome since 1949 (Siboulet, 1951, 1955, 1957), and our own personal series consists of more than 500 cases. The numerous ways in which the syndrome presented and the wide variety of clinical signs have suggested many lines of research to elicit the cause of the disease.

Harkness $(1945,1950)$ suggested that the syndrome might have many causes, and thought that a virus aetiology was quite possible. Accordingly, we have investigated, on chick embryos, cultures of smears taken from the urethra and conjunctivae of patients suffering from this syndrome in whom inclusion bodies identical with virus inclusion bodies had been demonstrated in urethral epithelial cells.

The remarkable results obtained by Jones, Collier, and Smith (1959) and Collier (1961) in trachoma and inclusion blennorrhoea have encouraged us to attempt and pursue these researches.

This is a summary of the results obtained from three patients affected by the urethro-conjunctivosynovial syndrome: the first and second were seen in the Urological Department of the Hôpital SaintLouis (Pr. R. Kuss), and the third in private practice.

\section{Clinical Course}

The three patients were 29,35 , and 44 years old. In each case an abacterial urethritis was the first sign

\footnotetext{
* Paper read to M.S.S.V.D. in London on January 26, 1962.
}

and was followed by arthritis and ocular involvement. There was marked asthenia and painful myalgia. There had been no exposure to infection immediately before the appearance of the clinical signs. In one case a transient diarrhoea occurred just before the onset of clinical signs. The patients were referred to us because detailed examination had failed to reveal the aetiology of the condition and the numerous investigations had been negative.

\section{Material and Methods}

(1) Virus Inclusion Bodies in the Urethral Epithelial Cells.-Our urethral biopsies are performed with a curette and are always done after prostatic massage. Specimens from all three cases, stained with Giemsa stain showed inclusions identical in appearance with virus inclusion bodies. These inclusion bodies in the epithelial cells showed three characteristics; they were crescentic in shape, double-poled, and situated far away from the nucleus (Figs 1 and 2, overleaf).

(2) Culture.-To test the theory of virus aetiology we cultured material from the urethral smears, using a similar technique to that used for the smears and inoculated medium in a tube containing $0.6 \mathrm{ml}$. of a solution of Hanks's medium or of phosphate at a pH of $7 \cdot 2$, to which was added streptomycin to inhibit bacterial growth. Two or 3 hours after the scrapings were taken, the eggs were inoculated.

The following technical points are emphasized:

(i) The eggs were disinfected with iodine in alcohol and a 2 to $3 \mathrm{~cm}$. perforation was made over the air space.

(ii) The material from the urethral curettage was crushed on to ice in a micro-crushing machine to prevent destruction of the virus by heating. 
(iii) The material was drawn into a syringe with a needle of $5 \mathrm{~cm}$. in length attached.

(iv) The eggs were held vertically with a 20 to $25^{\circ}$ inclination from the long axis and the needle was inserted vertically to a depth of about $2.5 \mathrm{~mm}$.

(v) The material was injected with the needle as far as possible behind the embryo to prevent injury to it.

(vi) The material was kept constantly moving on the tray of an electro-magnetic device in a cup containing ice. In this way the material became homogeneous and the dispersion of the virus was identical in all the eggs.

Six eggs were inoculated from each patient. Two eggs were used as controls and inoculated with the fluid containing streptomycin, two were inoculated with urethral material, and one with material from each eye.

The inoculated eggs were inspected by being held up to the light, and if death of the embryo occurred after 5 days it could be attributed to the effect of the virus. If death occurred before the fifth day it was regarded as probably due to some technical error.

The eggs were opened on the sixth day, i.e. 2 to 3 days before hatching, through a hole in the air space. The contents were placed in a Petri dish. A small piece of the yolk sac was cut off as near as possible to the junction between the yolk sac and the viscera. The yolk was then filtered through filter paper and a smear was made on a microscopic slide.

The smear was allowed to dry, fixed with methyl alcohol for 3 minutes, and washed with water. The staining was carried out by Giemsa's technique.

The liver, heart, and brain were removed from the six eggs, and special sections were cut and prepared by Dr. Chomé, using special staining methods.

\section{Results}

Smears.-Extremely small, red elementary bodies with a purple nucleus and blue cytoplasm were seen (Fig. 3). After several passages the quantity of virus increased and produced inclusion bodies which were sometimes scattered about the cytoplasm and sometimes close to the nucleus, forming crescents or outlines resembling a gendarme's cap.

Pathological Anatomy.-The elementary bodies were not numerous in the liver, and heart, and were extremely small and difficult to see. The brain was increased in size and showed intense congestion (Fig. 4).
Malformations of the Chick Embryo.-Of the twelve eggs inoculated with material from the three patients, eight showed chick embryo malformations (Figs 5 and 6). No malformations were found in the controls.

Haemorrhagic lesions were visible in many parts of the body. The integument of the inoculated embryo was intensely congested and oedematous at the level of the neck. In some cases the body was oedematous and transparent and the viscera could be seen through it. Haemorrhages around the follicles of the feathers were also observed.

The embryos were not as well developed as the non-inoculated specimens. Absence of one eye, emaciation, distortion of feather development, retardation, and sometimes absence of growth were noted. The skin was haemorrhagic, weak, and friable, and layers could be more easily separated for making smears than in the non-inoculated specimens. Considerable inflammatory reactions in the viscera, with congestion and hypertrophy of the liver were also found. It appears that these malformations of the chick embryo must be attributed to the action of the virus.

\section{Discussion}

The urethral scrapings were taken before any local treatment was given and during the acute phase of the disease. Similar inclusion bodies have never been found in normal subjects, which is a strong argument in favour of a virus aetiology. Nor were elementary or initial bodies found in cultures of non-inoculated eggs. The malformations caused by the virus which we have called "chlamydozoon oculo-genitale" were very similar to those caused by the psittacosis-trachoma group.

The average incidence of congenital malformations in incubator-bred chicks in France is 1 in every 10,000 , but in our series of 42 inoculated eggs, thirteen ( 31 per cent.) malformed chicks were found, whereas none occurred in 22 non-inoculated eggs.

\section{Summary}

A virus aetiology appeared probable in three cases of urethro-conjunctivo-synovial syndrome, because bodies very similar to virus inclusion bodies were found in the urethral epithelial cells, because elementary and initial bodies were isolated in chick embryos which closely resembled those found in well-known virus diseases, and because of the occurrence of malformations of the chick embryo in the inoculated eggs. 

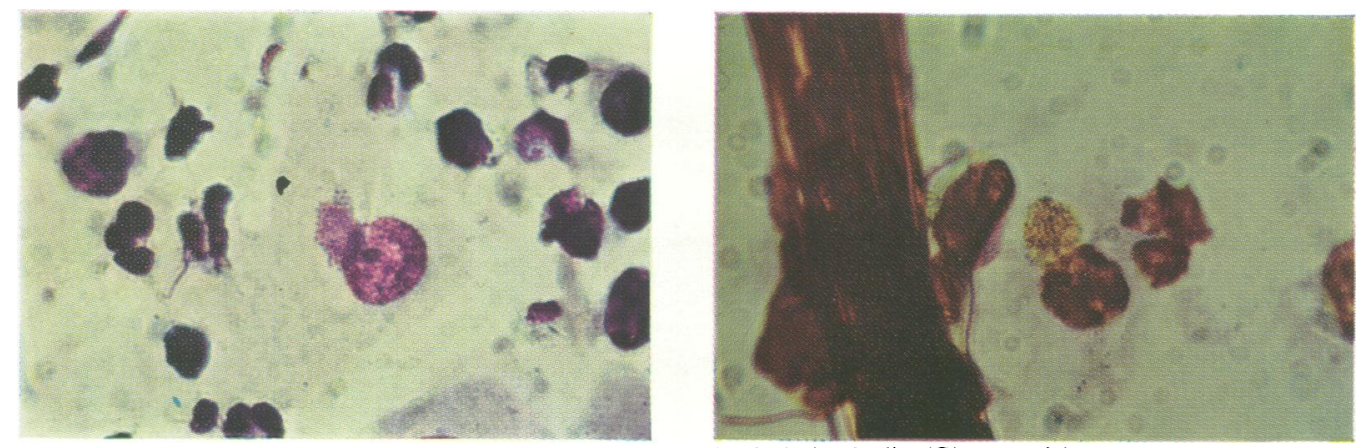

FIGs 1 and 2.-Urethral epithelial cells, showing inclusion bodies (Giemsa stain).
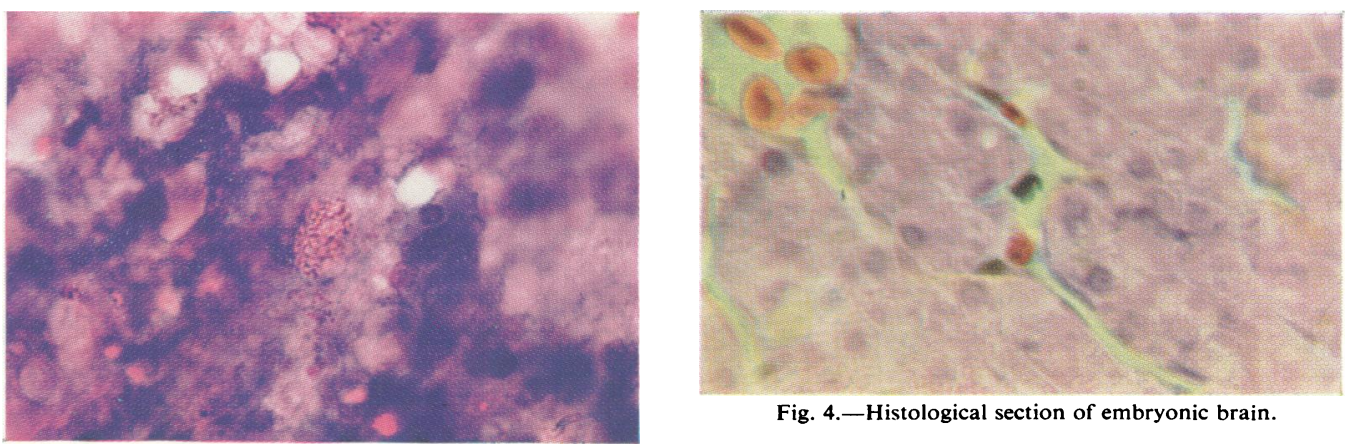

Fig. 4.-Histological section of embryonic brain.

Fig. 3.-Yolk sac culture smear, showing elementary bodies.
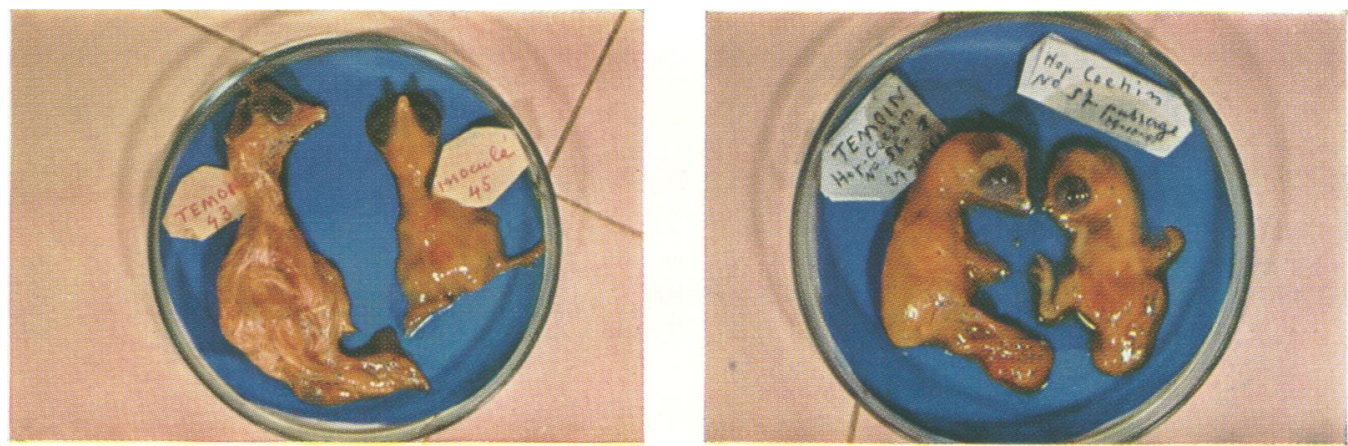

FIGS 5 and 6.-Embryonic malformations.

Facing p. 210 
We should like to thank especially Mesdames $\mathrm{H}$. Jouveau-Dubreuil, and M. Slomkowski, and Mademoiselle M. A. Beaujeu for their technical help.

\section{REFERENCES}

Collier, L. H. (1961). Lancet, 1, 795.

Harkness, A. H. (1945). Brit. J. vener. Dis., 21, 93. (1950). "Non-Gonococcal Urethritis", p. 67. Livingstone, Edinburgh.

Jones, B. R., Collier, L. H., and Smith, C. H. (1959). Lancet, 1, 902.

Pernod, S., and Mesmin, Y. (1961). Sem. Hôp. Paris, 37, 2291.

Siboulet, A. (1951). Presse méd., 59, 630. (1955). Brit. J. vener. Dis., 31, 235.

- (1957). Bull. Soc. Méd. Paris, 161, No. 9, p. 7.
Arguments en faveur de l'étiologie virale de certaines urétrites non-gonococciques; à propos de trois cas de syndrome urétro-conjonctivo-synovial

\section{RÉSUMÉ}

Dans trois cas de syndrome de Fiessinger-LeroyReiter, un certain nombre de faits constituant des arguments en faveur d'une étiologie virale sont rapportés-à savoir (1) la présence d'inclusions virales dans les cellules épithéliales urétrales, (2) la présence de corps élémentaires et de corps initiaux en culture sur l'oeuf embryonnaire et à l'examen des coupes histologiques des embryons, (3) l'existence de malformations embryonnaires non observées chez les témoins. 